\title{
ИЗМЕНЕНИЕ КОММУНИКАТИВНОЙ ТОЛЕРАНТНОСТИ СТУДЕНТОВ ПСИХОЛОГОВ В ПЕРИОД ОБУЧЕНИЯ В ВУЗЕ
}

\section{CHANGES IN THE COMMUNICATIVE TOLERANCE OF PSYCHOLOGY STUDENTS DURING THE PERIOD OF STUDY AT THE UNIVERSITY}

\section{E. Stoyanova Yu. Zhivaeva T. Kazakova V. Kembel}

Summary: The article presents the results of a study of the communicative tolerance of psychology students at different stages of study at a university during the transition from course to course. Communicative tolerance is considered as a key characteristic of the professional competence of a psychologist. As a result, no dynamic indicators of communicative tolerance were found during the transition from course to course. Minor changes in communicative tolerance were recorded from the first to the fourth year.

Keywords: communicative tolerance, training, psychologists, professionally important qualities.
Стоянова Екатерина Иннокентьевна

Доцент, ФГБОУ ВО «Красноярский государственный медицинский университет им. проф. В.Ф. Войно-Ясенецкого» Katya-chernova@yandex.ru

Живаева Юлия Валерьяновна

Доцент, ФГБОУ ВО «Красноярский государственный медицинский университет им. проф. В.Ф. Войно-Ясенецкого» yul-zhivaeva@yandex.ru

Казакова Татьяна Вячеславовна

Д.м.н., профессор, ФГБОУ ВО «Красноярский государственный медицинский университет им. проф. В.Ф. Войно-Ясенецкого» kazak-tv@mail.ru

Кембель Вера Радионовна

Доцент, ФГБОУ ВО «Красноярский государственный медицинский университет им. проф. В.Ф. Войно-Ясенецкого» vera.kembel@mail.ru

Аннотация: В статье представлены результаты исследования коммуникативной толерантности студентов психологов на разных этапах обучения В вузе при переходе от курса к курсу. Коммуникативная толерантность рассматривается как ключевая характеристика профессиональной компетентности психолога. В результате при переходе от курса к курсу динамических показателей коммуникативной толерантности не обнаружено. Зафиксированы незначительные изменения в коммуникативной толерантности от первого к четвертому курсу.

Ключевые слова: коммуникативная толерантность, обучение, психологи, профессионально важные качества.

\section{Введение}

$\mathrm{B}$ настоящее время проблема изучения профессионально важных качеств психологов актуальна, так как государственный образовательный стандарт высшего профессионального образования предъявляет достаточно высокие квалификационные требования к выпускнику вуза по специальности «Клиническая психология».

В теории вопроса, несмотря на различные подходы к решению проблемы развития профессионально важных качеств в процессе обучения психологов, существует ряд нерешенных проблем, наиболее актуальной из них является отсутствие четкой системы критериев отбора профессионально важных качеств психолога. Потребность в наличии четкой определенной классификации профессионально важных качеств очевидна как для соз- дания стройной и непротиворечивой концепции, так и построения модели консультирования по развитию профессионально важных качеств.

Отсутствие в научной литературе единого (полного) перечня профессионально важных качеств, вероятно, можно объяснить трудностями, связанными с разграничением личностных и профессионально важных качеств будущего психолога.

Следует также отметить, что профессионально важные качества являются основными качествами в профессиональной деятельности: их наличие и развитие предопределяют успешность или неуспешность педагога-психолога в дальнейшей работе.

Не менее важной является и проблема прикладного характера: в современной практике вузовской под- 
готовки педагогов-психологов не уделяется должного внимания формированию и развитию профессионально важных качеств (в частности, эмпатии, эмоциональной устойчивости, толерантности) у студентов специальности «Клиническая психология» как в теоретическом, так и практическом аспектах.

Этим и продиктована актуальность нашего исследования.

Формулировка цели и задач. Цель исследования определить изменения коммуникативной толерантности студентов специальности «Клиническая психология»

Гипотеза: мы предполагаем, что могут существовать различия в коммуникативной толерантности у студентов 1, 2, 3, 4, 5 курсов специальности «Клиническая психология».

Практическая значимость исследования заключается в определении уровня развития профессионально важных качеств у студентов специальности «Педагогика и психология», а также в разработке модели социально-психологического тренинга по развитию профессионально важных качеств (эмпатии, эмоциональной устойчивости, толерантности) и в возможности ее применения в профессиональной деятельности педагогапсихолога.

База исследования: ФГБОУ ВО КрасГМУ им проф. В.Ф. Войно-Ясенецкого 1, 2, 3, 4, 5 курсы специальности «Клиническая психология».

\section{$* * *$}

В отечественной и зарубежной психологии существует множество подходов к исследованию личности, но в последние годы возрос интерес к прикладному аспекту этого психологического направления - исследованию профессиональных и личностных качеств психологов (Г.С. Абрамова, Н.А. Аминов, Р.В. Овчарова, Н.И. Обозов, М.В. Молоканов, В.Ю. Моховиков и др.) [1, с. 240]. Во многих исследовательских работах отмечается определенная зависимость между личностными качествами психолога и эффективностью в профессиональной деятельности (М.В. Молоканов, И.Г. Сизова, Е.В. Юдина и др.) [3, с.145]. Более подробно мы рассмотрим концепции профессионально важных качеств Е.А. Климова, Р. Кочюнаса, а также клиент-центрированный подход К. Роджерca $[7$, c.31].

С точки зрения клиентов, личные качества психолога выходят на первый план по отношению к профессиональным. И, соответственно, отсутствие участия, открытости, способности внушать доверие могут в большей степени оказать негативное влияние на процесс взаимо- действия между клиентом и психологом [6, с.140].

Существует множество точек зрения относительно понятия толерантность. В культурологии под толерантностью понимается терпимость, снисходительность к чужим мнениям, верованиям, поведению, обычаям, культуре, чувствам, идеям, один из основных демократических принципов [9, с.544].

В педагогике это одно из важнейших качеств педагога. В основе толерантности лежит способность учителя адекватно оценивать реальную ситуацию, с одной стороны, и возможность предвидеть выход из ситуации, с другой стороны. Формирование толерантности - одна из важнейших задач профессионального воспитания учителя.

В психологии одним из определений термина можно считать следующее: «Толерантность (от латинского «tolerantia» - терпение) - отсутствие или ослабление реагирования на какой- либо неблагоприятный фактор в результате снижения чувствительности к его воздействию [5, с.388].

Однако в психологических исследованиях последних лет авторы уточняют, структурируют понятие толерантности.

Л.И. Иванова определяет толерантность как личностное свойство, которое показывает отношение человека к другим людям (например, положительное или отрицательное) $[4$, с.55].

Толерантность приводит к повышению устойчивости («терпимости») к некоторому неблагоприятному фактору. Социально-психологическое понимание толерантности предполагает терпимость к различным мнениям, непредубежденность в оценке людей и событий. В одном случае социально-психологическая терпимость может быть обусловлена низкой социально-психологической чувствительностью личности («черствый», «холодный»). По существу, именно в таком варианте терпимость определяется толерантностью и связана с повышением порога социально-психологической чувствительности партнеров к различным воздействиям. Другой путь обеспечения социально-психологической терпимости личности - это специфика ее установок («Все люди могут ошибаться», «Чем больше точек зрения, тем лучше», «Каждый имеет право на свое мнение»). В данном случае проявление терпимости связано с формированием соответствующих установок личности.

Таким образом, в структуре общего феномена терпимости можно выделить два вида: 1) сенсуальная терпимость личности и 2) диспозиционная терпимость личности [8, с.149]. 
Сенсуальная терпимость связана с устойчивость личности к воздействиям среды, с ослаблением реагирования на какой-либо неблагоприятный фактор за счет снижения чувствительности.

Таким образом, сенсуальная терпимость связана с классической толерантностью, с повышением порога чувствительности к различным условиям среды, в том числе воздействиям субъектов межличностного взаимодействия. Образно говоря, сенсуальная терпимость есть терпимость-черствость, терпимость-стена.

В основе диспозиционной терпимости лежит принципиально иной механизм, обеспечивающий терпимость личности при взаимодействиях со средой. В данном случае речь идет о предрасположенности, готовности личности к определенной (в данном случае - терпимой) реакции на среду. За диспозиционной терпимостью стоят определенные установки личности, совокупность её отношений к действительности: к другим людям, к их поведению, к себе, к воздействию других людей на себя, к жизни вообще. Примерами установок, обеспечивающими диспозиционную терпимость личности, являются такие, как: «Все люди когда-нибудь ошибаются», «Чем больше точек зрения, тем лучше», «Агрессия и раздражительность очень часто провоцируются ситуацией, а не является внутренней сущностью человека». Образно говоря, диспозиционная терпимость есть терпимостьпозиция, терпимость-установка, терпимость-мироощущение.

Вышеописанные феномены раскрывают явления терпимости как бы «изнутри личности». Также можно выделить три фактора, обуславливающих терпимость: социогенетический, микросредовой (психогенетический) и биогенетический.

Для осуществления эффективной деятельности психолога наиболее актуальной является коммуникативная толерантность. Под коммуникативной толерантностью понимается уважительное, безоценочное принятие информации, исходящей от клиента к психологу.

Современным психологом В.В. Бойко [2] дано подробное описание подструктур личности, обусловливающих коммуникативную толерантность, среди которых можно назвать следующие:

1. Интеллектуальная - передает парадигму (образец, тип, стиль) мыслительной деятельности конкретного человека, т. е. принципы его понимания действительности, привычные для него стереотипы осмысления проблем, идей, принятия решений.

2. Ценностно-ориентационная - вбирает в себя основные мировоззренческие идеалы конкретного человека, его жизненные ближайшие и отдален- ные цели, интересы, оценки происходящего.

3. Этическая - выражает нравственные нормы, которых придерживается человек. При этом проявляется та или иная степень включения совести в его мысли, оценки и действия: сказывается ориентация на добро и зло, справедливость или несправедливость, склонность руководствоваться чувством долга или привычка вести себя безответственно.

4. Эстетическая - охватывает область предпочтений, вкусов и чувств, особенности восприятия человеком красивого и безобразного, возвышенного и низменного, комического и трагического.

5. Эмоциональная - демонстрирует преобладающий спектр, в котором чаще всего пребывает данный человек: радость или печаль, оптимизм или пессимизм, возбужденность или спокойствие, подъем или подавленность, беззаботность или тревожность, миролюбие или агрессивность.

6. Сенсорная (чувственная) - включает особенности чувственного восприятия мира на уровне зрительного, слухового, обонятельного, вкусового, кожного и двигательного ощущений.

7. Энерго-динамическая - отражает энергетические свойства человека - качество и силу его энергетического поля. Качество излучаемой и распространяемой индивидом энергии зависит, как отмечалось, от ее знака - положительного, нейтрального или отрицательного.

8. Алгоритмическая - данная подструктура личности объединяет очень разные личностные качества, у которых тем не менее есть нечто общее однообразие воспроизводимости.

9. Характерологическая - сосредотачивает устойчивые, типообразующие черты личности, которые врожденны или приобретены под влиянием окружения в результате воспитания, примеров, подражания.

10. Функциональная - закрепляет различные системы жизнеобеспечения и поддержания комфорта личности - это прежде всего потребности, и возникающие на их основе предпочтения и желания.

Таким образом, толерантность даёт возможность приспособиться к неблагоприятным факторам, то есть носит адаптивный характер. Например, толерантность к тревоге, толерантность к чужой вере.

Понятие толерантности определяется также границами: человеку безразлично происходящее, пока оно не касается его самого. Таким образом, при толерантности снижен порог чувствительности личности как эмоциональное нереагирование на события, т.е. толерантность выступает как пассивная форма реагирования. Расширение сознания от сдержанности-выдержанности до принятия «другого», «иного», чем «я», делает мировос- 
приятие более многомерным, энергоемким, целостным, а значит, более адекватным реальности.

В исследовании приняли участие студенты 1, 2, 3, 4, 5 курсов медико-психолого-фармацевтического факультета, специальность «Клиническая психология». Выборку составили 59 человек в возрасте от 17 до 23 лет.

Исследование проходило в 5 этапов: Подбор психодиагностических методов и методик; Сбор данных; Обработка данных: первичная обработка данных заключалась в составлении сводных таблиц эмпирического исследования Вторичная обработка данных включала в себя их количественный и качественный анализ, определение уровня развития эмпатии, эмоциональной устойчивости, толерантности у студентов 1, 2, 3, 4, 5, курсов с помощью критерия Крускала-Уоллиса $(\mathrm{H})$. Интерпретация результатов исследования. Формулировка выводов.

В процессе эмпирического исследования были использованы следующие психодиагностические методики: «Коммуникативная толерантность».

Целью методики «Коммуникативная толерантность» является выявление уровня толерантности у испытуемых.

Испытуемым выдается бланк, на котором предложены 9 ситуаций, в которых проявляются их особенности поведения. К данным ситуациям предлагается 5 вариантов суждений, с каждым из которых нужно либо согласиться, не высказать точного отношения, либо полностью не согласиться.

Целью критерия Крускала-Уоллиса является оценка различий одновременно между тремя, четырьмя и т.д. выборками по уровню какого-либо признака. Полученные результаты при применении критерия были подсчитаны с помощью формулы:

$$
H=\left[\frac{12}{N(N+1)} \cdot \sum \frac{T_{j}^{2}}{n}\right]-3(N+1)
$$

где N -общее количество испытуемых в объединенной выборке;

n-количество испытуемых в каждой группе;

Т-сумма рангов по каждой группе;

С помощью описанных выше методик на данном этапе исследования нами были получены эмпирические данные, анализ и интерпретация которых содержится в следующем параграфе.

По методике «Коммуникативная толерантность» (были получены данные, которые отражены в табл.1).

Таблица 1. Результаты исследования коммуникативной толерантности студентов (в \%)

\begin{tabular}{|c|c|c|c|}
\multirow{2}{*}{ Курс } & \multicolumn{3}{|c|}{ Уровни коммуникативной толерантности } \\
\cline { 2 - 4 } & Высокий & Средний & Низкий \\
\hline 1 & 50 & 44 & 6 \\
\hline 2 & 28 & 72 & - \\
\hline 3 & 60 & 30 & 10 \\
\hline 4 & 75 & 25 & - \\
\hline 5 & 36 & 64 & - \\
\hline
\end{tabular}

Как видно из табл. 1, из общего количества студентов первого курса высокий уровень коммуникативной толерантности наблюдается у 50 \% студентов, средний уровень - у 44 \% студентов, низкий уровень коммуникативной толерантности - у 6\% студентов. Это можно объяснить тем, что на первом курсе студенты находятся на стадии адаптации к новой социальной ситуации и новой социальной роли. Поэтому еще не знают, как вести себя в данной ситуации, и, возможно, поэтому коммуникативно терпимы и сдержаны. Возможно, у них существует определенный образ психолога, которому нужно соответствовать. Данные результаты говорят о достаточно благоприятной ситуации, так как это качество находится на достаточно высоком уровне развития.

На втором курсе у 28 \% студентов наблюдается высокий уровень коммуникативной толерантности, у 72 \% студентов - средний уровень, низкого уровня коммуникативной толерантности выявлено не было. Результаты говорят о том, что на втором курсе они уже более коммуникативно раскрепощены. Данный этап является накопительным этапом знаний, т.е. они еще у них только еще формируется определенная модель поведения психолога.

На третьем курсе у 60 \% студентов зафиксирован высокий уровень коммуникативной толерантности, у $30 \%$ студентов - средний уровень и у 10 \% студентов наблюдается низкий уровень коммуникативной толерантности.

На четвертом курсе высокий уровень коммуникативной толерантности наблюдается у 75 \% студентов, у 25 $\%$ - средний уровень, низкого уровня коммуникативной толерантности выявлено не было.

На четвертом и пятом курсах низкого уровня коммуникативной толерантности выявлено не было. В то же время результаты исследования пятого курса говорят о снижении высокого уровня коммуникативной толерантности (36\%) в сторону среднего уровня (64\%). Вероятно, у части студентов уменьшается желание изменить себя в соответствии с какими-то идеальными представления- 
ми, этот факт подтверждается в психологических исследованиях ПВК студентов-психологов [22, с.10].

Таким образом, результаты на всех курсах свидетельствуют о преобладании высокого уровня коммуникативной толерантности студентов специальности «Педагогика и психология». Это говорит о том, что они могут достаточно легко строить взаимоотношения с другими людьми, входить с ними в контакт и взаимодействовать. В целом изменения в показателях по уровню коммуникативной толерантности находятся в неустойчивом состоянии при переходе от курса к курсу, хотя и имеет место преобладание высокого уровня данного качества у студентов.

Результаты проведенного исследования, в ходе которого был применен критерий $(\mathrm{H})$, показали, что коммуникативная толерантность $\left(\mathrm{H}_{\text {эмп }}=1,98\right.$ при $\mathrm{H}_{\mathrm{kp}}=9,488^{* *}$, $\left.\mathrm{n}_{1}=16, \mathrm{n}_{2}=18, \mathrm{n}_{3}=10, \mathrm{n}_{4}=4, \mathrm{n}_{5}=11\right)$ при переходе от курса $\mathrm{k}$ курсу не изменяется.

Таким образом, различий в показателях по проведенному исследованию с применением критерия КрускалаУоллиса $(\mathrm{H})$ не было обнаружено. Это свидетельствует о том, что при переходе от курса к курсу у студентов специальности «Педагогика и психология» исследуемые качества не изменяются.

\section{Выводы}

Не обнаруживается изменений коммуникативной то- лерантности и эмоциональной устойчивости, что может говорить еще о недостаточной личностной зрелости студентов, но также, возможно, у некоторых студентов идет формирование этих качеств, в результате чего очень трудно проследить их развитие. Опираясь на результаты психологических исследований, можно сделать вывод о том, что студенты становятся более консервативными и ригидными, с сомнением относятся к новым идеям, противятся переменам. Следовательно, необходимо развивать в них коммуникативную толерантность. Вероятно, наиболее целесообразным является включение в теорию и практику профессиональной подготовки психологов систематических мероприятий по развитию базовых профессионально важных качеств. Теория и практика в своей совокупности, по-видимому, дадут возможность построить модель идеального психолога с присущими ему профессиональными знаниями, умениями и навыками и возможностью эффективно пользоваться ими в своей работе.

Проведенное исследование по выявлению аспектов развития профессионально важных качеств показало: по результатам методики «Коммуникативная толерантность» наблюдается достаточно высокий уровень коммуникативной толерантности у студентов 1-4 курсов специальности «Клиническая психология» и снижении данного показателя у студентов 5 курса.

Отсутствие изменения толерантности у студентов всех курсов специальности «Клиническая психология».

\section{ЛИТЕРАТУРА}

1. Абрамова Г.С. Практическая психология. - Екатеринбург: Деловая книга, 1998. - 368 с.

2. Бойко В.В. Энергия эмоций в общении: взгляд на себя и на других. - М.,1996.

3. Ежова Н.Н. Рабочая книга практического психолога. - Ростов н/Д.: Феникс, 2004. - 320 с.

4. Иванова Н.Л. Идентичность и толерантность: соотношение этнических и профессиональных стереотипов. // Вопр. психол. - 2004. - № № 6 - С.54-60.

5. Карпенко Л.А. Краткий психологический словарь /Под общ. ред. А.В. Петровского, М.Г. Ярошевского. - Ростов н/Д.: Феникс, 1999. - 512 с.

6. К Кованов А.Ю. Личное и профессиональное Я в практике психосоциального консультирования. // Мир психологии. - 2002 - №2 - С.135-142.

7. Нельсон-Джоунс Р. Теория и практика консультирования - СПб.: Питер, 2000. - 464 с.

8. Реан А.А., Коломинский Я.Л. Социальная педагогическая психология. - СПб.: Питер, 1999. - 416 с.

9. Х Хоруженко К.М. Культурология. Энциклопедический словарь. - Ростов н/Д.: Феникс, 1997. - 640 с. 